\title{
Sleep quality and work among nursing vocational students
}

\author{
Qualidade do sono e trabalho entre estudantes de técnico em enfermagem \\ La calidad del sueño y el trabajo de los estudiantes de técnico de enfermeira
}

Universidade Estadual de Londrina. Londrina, Paraná, Brazil. "Universidade Estadual do Norte do Paraná. Bandeirantes, Paraná, Brazil.

\begin{abstract}
Kawanna Vidotti Amaral' ORCID: 0000-0001-7264-7530
\end{abstract}

Maria José Quina Galdino" ORCID: 0000-0001-6709-3502

Júlia Trevisan Martins' ORCID: 0000-0001-6383-7981

\section{How to cite this article:}

Amaral KV, Galdino MJQ, Martins JT. Sleep quality and work among nursing vocational students.

Rev Bras Enferm. 2021;74(6):e20201285. https://doi.org/10.1590/0034-7167-2020-1285

\section{Corresponding author: \\ Kawanna Vidotti Amaral \\ E-mail:kawannava@gmail.com

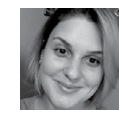

EDITOR IN CHIEF: Antonio José de Almeida Filho ASSOCIATE EDITOR: Carina Dessotte

Submission: $12-28-2020$

Approval: 04-12-2021

\begin{abstract}
Objectives: to analyze quality of sleep among students of technical courses in nursing according to the exercise of work activity. Methods: a cross-sectional and analytical research, with 213 students from Paraná. Characterization data and the Pittsburg Sleep Quality Index were collected between March and June 2020 and analyzed descriptively and inferentially. Results: quality of poor sleep was $76.5 \%$ among those who work and $75.3 \%$ among those who do not work. Difficulty in reconciling personal and academic life ( $p=0.016{ }^{\text {,adj }} \mathrm{OR}: 3.450$ ) and indicating anxiety due to school activities ( $p=0.017$;adjOR:3.236) increased the chances of poor sleep quality among working students. Satisfaction with health reduced the chances of poor sleep quality, regardless of exercising work activity ( $p=0.002 ;$;ajoR:0.210) or not

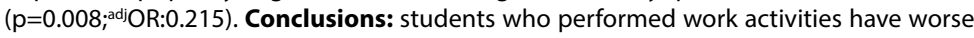
sleep quality due to anxiety and the multiple activities to be reconciled with the study.
\end{abstract} Descriptors: Sleep; Sleep Deprivation; Students, Nursing; Education, Nursing, Associate; Work.

\section{RESUMO}

Objetivos: analisar a qualidade do sono entre estudantes de cursos técnicos em enfermagem segundo o exercício de atividade laboral. Métodos: pesquisa transversal e analítica, com 213 alunos paranaenses. Dados de caracterização e o Índice da Qualidade do Sono de Pittsburg foram coletados entre março e junho de 2020 e analisados descritiva e inferencialmente. Resultados: a qualidade do sono ruim foi de $76,5 \%$ entre os que trabalham e de $75,3 \%$ entre os que não trabalham. Dificuldade de conciliar vida pessoal e acadêmica $\left(p=0,016 ; \mathrm{R}^{\mathrm{aj}}: 3,450\right)$ e indicar ansiedade devido às atividades escolares $\left(p=0,017 ; \mathrm{OR}^{\mathrm{aj}}: 3,236\right)$ aumentaram as chances de qualidade do sono ruim entre os alunos que trabalham. A satisfação com a saúde reduziu as chances de qualidade do sono ruim, independente de exercer atividade laboral $\left(p=0,002 ; O R^{\mathrm{aj}}: 0,210\right)$ ou não $\left(p=0,008 ; \mathrm{OR}^{\mathrm{aj}}: 0,215\right)$. Conclusões: os estudantes que exerciam atividades laborais apresentam pior qualidade do sono devido à ansiedade e as múltiplas atividades a serem conciliadas com o estudo.

Descritores: Sono; Privação do Sono; Estudantes de Enfermagem; Educação Técnica em Enfermagem; Trabalho.

\section{RESUMEN}

Objetivos: analizar la calidad del sueño en estudiantes de cursos técnicos en enfermería según el ejercicio de la actividad laboral. Métodos: investigación transversal y analítica, con 213 estudiantes de Paraná. Los datos de caracterización y el Índice de Calidad del Sueño de Pittsburg se recopilaron entre marzo y junio de 2020 y se analizaron de forma descriptiva e inferencial. Resultados: la calidad del mal sueño fue del $76,5 \%$ entre los que trabajan y del $75,3 \%$ entre los que no trabajan. La dificultad para conciliar la vida personal y académica $\left(p=0,016 ; \mathrm{OR}^{\mathrm{aj}}: 3,450\right)$ y la indicación de ansiedad por las actividades escolares $\left(\mathrm{p}=0,017 ; \mathrm{OR}^{\mathrm{a}}: 3,236\right)$ aumentaron las posibilidades de mala calidad del sueño entre los estudiantes trabajadores. La satisfacción con la salud redujo las posibilidades de mala calidad del sueño, independientemente de la actividad laboral $\left(\mathrm{p}=0,002 ; \mathrm{OR}^{\mathrm{a}}: 0,210\right)$ o no $\left(\mathrm{p}=0,008 ; \mathrm{OR}^{\mathrm{a}}: 0,215\right)$. Conclusiones: los estudiantes que realizaban actividades laborales presentaron peor calidad de sueño debido a la ansiedad y las múltiples actividades a conciliar con el estudio.

Descriptores: Sueño; Privación de Sueño; Estudiantes de Enfermería; Graduación en Auxiliar de Enfermería; Trabajo. 


\section{INTRODUCTION}

Sleep is essential for humans because of its function of physical restoration, conservation, energy and protection. This physiological condition is controlled by a period of drowsiness and wakefulness, and circadian rhythm occurs in the 24 hours and coordinates internal time according to external influences, such as light and darkness. Thus, its behavior is regulated by endogenous molecular clocks and its interruption can cause health problems, causing cognitive deficiencies and physical and mental diseases ${ }^{(1)}$.

The American Academy of Sleep Medicine and the Sleep Research Society guidelines indicated that adults aged 18 to 60 should have at least seven hours of sleep daily to achieve good quality life ${ }^{(2)}$. However, sleep may vary in quality and proportion of duration, depending on daily activities. Some people may adapt to a small sleep load to perform the cycle; while others, when exposing the multiplicity of tasks, decrease school performance and present metabolic and cardiovascular alterations ${ }^{(3)}$.

Having short sleep can lead to obesity, hypertension, dyslipidemia, and increased levels of systemic inflammatory markers ${ }^{(4)}$. Moreover, it causes attention deficit and decision-making power, which in turn can increase the number of accidents ${ }^{(5)}$. Thus, sleep quality was one of the factors that contributed to people being healthy ${ }^{(6)}$, as it was a protective factor for the emergence of diseases, especially those of a mental nature ${ }^{(7)}$. The literature indicated that poor sleep quality influences health and learning ${ }^{(8)}$.

Poor sleep quality was indicated as one of the disorders with a high incidence in nursing, which caused consequences on the physiological functioning of people, both during the day and night, interfering in the psychological and social aspects ${ }^{(9)}$.

It is known that, depending on the need for relocation in the labor market or desire to return or continue their studies for better professional training and salary rise, associated with the needs of maintenance of home, family members and payment of studies, makes people develop double or triple days of activities on the day. These activities lead students to regulate their day chronologically according to the time available for each activity, such as rest and sleep, eating conditions, time of locomotion of housing-work and work-study ${ }^{(10)}$.

From this, the difficulties related to reconciling work and study emerge and are evidenced by physical exhaustion, lack of time for academic or leisure activities, neglect of self-care, food, fun, difficulties in study funding and family distancing ${ }^{(10)}$.

A study conducted with Brazilian undergraduate nursing students showed that the prevalence of poor sleep quality for those who studied was $24.5 \%$ and for those who studied and worked, 59.8\%, being associated with sleepiness in the classroom and insomnia ${ }^{(11)}$. A study developed in Egypt revealed that undergraduate students during the nursing internship had a prevalence of $90.5 \%$ of poor sleep quality ${ }^{(12)}$.

Although sleep is directly related to the maintenance of a good quality of health, there are still few studies on this theme in academic environments ${ }^{(13)}$, especially comparing to the concomitance of study with work activity. We defend the hypothesis that students who work have a higher chance of poor sleep quality than those who do not. Thus, studying the theme of sleep quality in students of nursing vocational courses is of unique importance, as it will provide new knowledge, as well as may contribute to managers, students and mental health professionals seeking actions that maximize students' well-being and, in turn, more effective teaching and learning.

\section{OBJECTIVES}

To analyze the quality of sleep among students of vocational courses in nursing according to the exercise of work activity.

\section{METHODS}

\section{Ethical aspects}

The research project received approval by the Institutional Review Board of Universidade Estadual de Londrina. All participants signed the Informed Consent Form (ICF).

\section{Study design, period and location}

This is a quantitative research of cross-sectional and analytical design, carried out with students from all schools of vocational nursing courses in Londrina, a municipality in the countryside of Paraná State between March and June 2020. These are two public and two private with a total workload of 1,200 to 1,800 hours, distributed in three or four academic semesters. The description of this section followed the Strengthening the Reporting of Observational Studies in Epidemiology (STROBE).

\section{Population and sample; inclusion and exclusion criteria}

To define the study population, students aged 18 years or older who were attending the last two semesters, considering that workloads are identical in these periods in all courses, as well as the time when practical classes and internships take place in different health units, were included, so the experience is similar for all participants. Those on leave for any reason during the collection period were excluded.

The course coordination reported that 560 students were properly enrolled in these course periods. Thus, all students were invited to respond to the online survey, forwarded to students' emails provided by the course coordinators.

During the data collection period, 213 students participated in the study and this convenience sample was considered adequate to the proposed statistical analysis, in which 10 cases are needed for each variable inserted in the multiple model ${ }^{(14)}$.

\section{Study protocol}

Data collection occurred using two instruments. The first contained the following sociodemographic, academic and living conditions data: age, sex, marital status, children, living with family, physical activity (frequency and duration), exercise of work activity, more than one employment relationship, leisure opportunities, monthly family income, sufficient money for needs, satisfaction with health and quality of life, use of study-related medication (including analgesics, anxiolytics, antidepressants, antibiotics, antiulcers, antihypertensives, anti-inflammatory or 
corticosteroids, muscle relaxers or others), type of vocational course, semester attended, course shift, interpersonal relationships, satisfaction with the study, concerns or difficulties faced in the study and influence of study on personal and social life. This instrument was submitted to a pilot test with 30 students from vocational courses in a neighboring municipality, who considered the questionnaire appropriate to the object of the study, and any alteration was unnecessary.

The second refers to the Pittsburg Sleep Quality Index (PSQI), a version translated and validated for Brazilian Portuguese, which has previously established reliability and validity. This instrument has 13 questions that, after transformation, generates seven components related to sleep: subjective quality, latency (time to start sleep), duration, habitual efficiency and sleep-related disorders, as well as the use of sleep medication and daytime dysfunction. Component scores are summed together to give an overall PSQI score, which ranges from 0 to $21^{(15)}$. In the sample of this study, Cronbach's alpha value was $a=0.704$.

For data collection, a single instrument was built on the Google Forms platform, in the following order: ICF (page 1), characterization questions sociodemographic, academic and living condition (page 2) and PSQI (page 3). PSQI items have been configured as a mandatory response.

Between March and June 2020, all students were invited to participate in the study by e-mail (registered individually), which contained the link that directed to ICF. After consent, access to the online questionnaire was allowed.

\section{Analysis of results, and statistics}

Data analysis was performed using the Statistical Package of Social Sciences (SPSS), version 20.0. Categorical variables were described by absolute and relative frequencies. The Wald Chi-Square Test was used to determine the differences among participants according to the exercise or not of work activity.
In the first stage of inferential statistics, we chose to start univariate binary logistic regressions, which compared a dichotomous categorical dependent variable with categorical independent variables using the Wald Chi-Square Test. Subsequently, to obtain the set of exposure variables that best explain the outcome, multiple binary logistic regressions were performed, as they allow the inclusion of more than one independent variable and adjustment variables ${ }^{(14)}$. Thus, univariate analyses were performed by binary logistic regressions, according to the exercise of work activity, to analyze the relationship of the general score of PSQI that was dichotomized in good ( $\leq 4$ points) or poor ( $\geq 5$ points) ${ }^{(15)}$ with predictive variables.

In the second stage, multiple binary logistic regressions were performed using the stepwise forward method, in which all independent variables that presented $p<0.20$ were added individually, remaining only those with statistical significance $(p<0.05)$. To adjust the relationship, the variables gender, age and having more than one employment relationship were added to the model. The model adjustment and its explained variation were verified by the Hosmer-Lemeshow and Nagelkerke R Square tests, respectively. The results were presented in Odds Ratio (OR) unadjusted and adjusted with $95 \%$ confidence intervals $(95 \% \mathrm{Cl})$.

\section{RESULTS}

Of the 560 eligible, 213 students participated in the study, most of them female, aged 18 to 29 years, with children, who lived with their families, private school courses and who reconciled work activities and study (Table 1).

Students indicated as drug classes used and that they understood to be related to the study: analgesics (19.3\%), anxiolytics (9.9\%), antidepressants (7.5\%) and muscle relaxers (11.7\%), and other classes were not mentioned.

Table 2 showed measures of central tendency and variability of PSQI.

Table 1 - Description of sociodemographic characteristics and living, health and academic conditions according to the exercise of work activity in students of vocational nursing courses ( $n=213)$, Londrina, Paraná, Brazil, 2020

\begin{tabular}{|c|c|c|c|c|c|c|}
\hline \multirow{2}{*}{ Variables } & \multicolumn{5}{|c|}{ Work activity } & \multirow{2}{*}{$p$ value* } \\
\hline & $\mathbf{n}$ & No & $\%$ & $\mathbf{n}$ & Yes & \\
\hline \multicolumn{7}{|l|}{ Sex } \\
\hline Female & 74 & & 40.7 & 108 & 59.3 & 0.048 \\
\hline Male & 7 & & 22.6 & 24 & 77.4 & \\
\hline \multicolumn{7}{|l|}{ Age group } \\
\hline $18 \mathrm{l}-\mathrm{-} 29$ years old & 60 & & 46.9 & 68 & 53.1 & 0.001 \\
\hline $30 \mathrm{l}-\mathrm{-} 53$ years old & 21 & & 24.7 & 64 & 75.3 & \\
\hline \multicolumn{7}{|l|}{ Marital status } \\
\hline Single or separate & 47 & & 39.2 & 73 & 60.8 & 0.697 \\
\hline Married & 34 & & 36.6 & 59 & 63.4 & \\
\hline \multicolumn{7}{|l|}{ Children } \\
\hline No & 51 & & 44.3 & 64 & 55.7 & 0.039 \\
\hline Yes & 30 & & 30.6 & 68 & 69.4 & \\
\hline \multicolumn{7}{|l|}{ Live with family } \\
\hline No & 4 & & 19.0 & 17 & 81.0 & 0.048 \\
\hline Yes & 77 & & 40.1 & 115 & 59.9 & \\
\hline \multicolumn{7}{|l|}{ Monthly household income ${ }^{* *}$} \\
\hline $0.5 \mathrm{I}-\mathrm{-} 2$ minimum wages & 70 & & 38.0 & 114 & 62.0 & 0.991 \\
\hline $2 \mathrm{l}-\mathrm{-} 10$ minimum wages & 11 & & 37.9 & 18 & 62.1 & \\
\hline \multicolumn{7}{|l|}{ Physically active ${ }^{* * *}$} \\
\hline No & 68 & & 39.3 & 105 & 60.7 & 0.420 \\
\hline Yes & 13 & & 32.5 & 27 & 67.5 & \\
\hline
\end{tabular}




\begin{tabular}{|c|c|c|c|c|c|}
\hline \multirow{2}{*}{ Variables } & \multicolumn{4}{|c|}{ Work activity } & \multirow{2}{*}{$p$ value* } \\
\hline & $\mathbf{n}$ & No & $\mathbf{n}$ & Yes & \\
\hline \multicolumn{6}{|l|}{ Leisure } \\
\hline Few opportunities & 66 & 34.6 & 125 & 65.4 & 0.002 \\
\hline Many opportunities & 15 & 68.2 & 7 & 31.8 & \\
\hline \multicolumn{6}{|l|}{ Money for needs } \\
\hline No & 77 & 38.5 & 123 & 61.5 & 0.573 \\
\hline Yes & 4 & 30.8 & 9 & 69.2 & \\
\hline \multicolumn{6}{|l|}{ Satisfaction with health } \\
\hline Dissatisfaction & 55 & 40.1 & 82 & 59.9 & 0.391 \\
\hline Satisfaction & 26 & 34.2 & 50 & 65.8 & \\
\hline \multicolumn{6}{|l|}{ Quality of life } \\
\hline Poor perception & 29 & 34.5 & 55 & 65.5 & 0.394 \\
\hline Good perception & 52 & 40.3 & 77 & 59.7 & \\
\hline \multicolumn{6}{|c|}{ Use of study-related medication } \\
\hline No & 44 & 36.7 & 76 & 63.3 & 0.642 \\
\hline Yes & 37 & 39.8 & 56 & 60.2 & \\
\hline \multicolumn{6}{|c|}{ Type of vocational course } \\
\hline Public & 39 & 63.9 & 22 & 36.1 & $<0.001$ \\
\hline Private & 42 & 27.6 & 110 & 72.4 & \\
\hline \multicolumn{6}{|l|}{ Semester attended } \\
\hline Penultimate & 12 & 60.0 & 8 & 40.0 & 0.037 \\
\hline Last & 69 & 35.8 & 124 & 64.2 & \\
\hline \multicolumn{6}{|l|}{ Course shift } \\
\hline Day & 16 & 41.0 & 23 & 59.0 & 0.671 \\
\hline Night shift & 65 & 37.4 & 109 & 62.6 & \\
\hline \multicolumn{6}{|c|}{ Relationship with most vocational course teachers } \\
\hline Good & 71 & 36.4 & 124 & 63.6 & 0.115 \\
\hline Poor & 10 & 55.6 & 8 & 44.4 & \\
\hline \multicolumn{6}{|c|}{ Relationship with most students in the course } \\
\hline Good & 63 & 39.1 & 98 & 60.9 & 0.558 \\
\hline \multirow{2}{*}{\multicolumn{6}{|c|}{ Influence of rhythm and intensity of study on life }} \\
\hline & & & & & \\
\hline No influence & 8 & 38.1 & 13 & 61.9 & 0.266 \\
\hline Positive influence & 62 & 36.0 & 110 & 64.0 & \\
\hline Negative influence & 11 & 55.0 & 9 & 45.0 & \\
\hline \multicolumn{6}{|l|}{ Satisfaction with studies } \\
\hline Dissatisfaction & 21 & 36.8 & 36 & 63.2 & 0.829 \\
\hline Satisfaction & 60 & 38.5 & 96 & 61.5 & \\
\hline \multicolumn{6}{|c|}{ Difficulty reconciling personal life and studies } \\
\hline No & 60 & 46.5 & 69 & 53.5 & 0.001 \\
\hline Yes & 21 & 25.0 & 63 & 75.0 & \\
\hline \multicolumn{6}{|c|}{ Interference of study demand on life } \\
\hline No & 65 & 35.9 & 116 & 64.1 & 0.135 \\
\hline Yes & 16 & 50.0 & 16 & 50.0 & \\
\hline \multicolumn{6}{|c|}{ Pressure from the pedagogical team for good performance } \\
\hline No & 69 & 37.3 & 116 & 62.7 & 0.575 \\
\hline Yes & 12 & 42.9 & 16 & 57.1 & \\
\hline \multicolumn{6}{|l|}{ Study-related anxiety } \\
\hline No & 42 & 34.1 & 81 & 65.9 & 0.173 \\
\hline Yes & 39 & 43.3 & 51 & 56.7 & \\
\hline
\end{tabular}

Note: *Wald Chi-Square; **minimum wage value in 2020: $R \$ 1,045.00 ; * * *$ activity more than $3 x$ and $\geq 150$ minutes/week.

Table 2 - Descriptive measures of the Pittsburg Sleep Quality Index among nursing vocational level students (n=213), Londrina, Paraná, Brazil, 2020

\begin{tabular}{|c|c|c|c|c|}
\hline \multirow{2}{*}{ Variables } & \multicolumn{4}{|c|}{ Descriptive measures } \\
\hline & Mean & Standard Deviation & Median & Minimum - Maximum \\
\hline Subjective sleep quality & 1.68 & 0.06 & 2.00 & $0.00-3.00$ \\
\hline Sleep latency & 1.23 & 0.06 & 1.00 & $0.00-3.00$ \\
\hline Sleep duration & 1.18 & 0.08 & 1.00 & $0.00-3.00$ \\
\hline Usual sleep efficiency & 0.44 & 0.07 & 1.00 & $0.00-3.00$ \\
\hline Sleep disorders & 0.99 & 0.03 & 1.00 & $0.00-2.00$ \\
\hline Use of sleeping medication & 0.94 & 0.08 & 2.00 & $0.00-3.00$ \\
\hline Daytime dysfunction & 0.86 & 0.05 & 1.00 & $0.00-2.00$ \\
\hline PSQI score & 7.31 & 0.24 & 7.00 & $0.00-16.00$ \\
\hline \multicolumn{5}{|l|}{ Sleep quality } \\
\hline Good & $51(23.9)^{*}$ & & & \\
\hline Poor & $162(76.1)^{*}$ & & & \\
\hline
\end{tabular}


Table 3 - Multiple models of factors associated with poor sleep quality in students of vocational nursing courses, according to working condition ( $\mathrm{n}=213$ ), Londrina, Paraná, Brazil, 2020

\begin{tabular}{|c|c|c|c|c|}
\hline Multiple Models & $\begin{array}{c}p \\
\text { value }\end{array}$ & $\begin{array}{c}\text { unadjusted Odds ratio } \\
\text { (95\% confidence interval) }\end{array}$ & $\begin{array}{c}p \\
\text { value }\end{array}$ & $\begin{array}{l}\text { adjusted Odds ratio* } \\
\text { (95\% confidence interval) }\end{array}$ \\
\hline \multicolumn{5}{|l|}{ No work activity** } \\
\hline Satisfaction with health & 0.014 & $0.267(0.093-0.767)$ & 0.008 & $0.215(0.069-0.671)$ \\
\hline \multicolumn{5}{|l|}{ With work activity*** } \\
\hline Difficulty reconciling personal life and studies & 0.017 & $3.417(1.246-9.370)$ & 0.016 & $3.450(1.254-9.493)$ \\
\hline Study-related anxiety & 0.014 & $3.238(1.265-8.291)$ & 0.017 & $3.236(1.233-8.494)$ \\
\hline Satisfaction with health & 0.001 & $0.206(0.081-0.529)$ & 0.002 & $0.210(0.080-0.551)$ \\
\hline
\end{tabular}

The prevalence of poor sleep quality was $76.5 \%$ among those who work and $75.3 \%$ among those who did not work $(p=0.841$; OR: 1,608; $95 \% \mathrm{Cl}$ : 0.560-2.038). The worst perception of latency for sleep ( $\mathrm{p}=0.008 ;$ OR: $0.623 ; 95 \% \mathrm{Cl}$ : 0.440-0.884) occurred among students who did not work. On the other hand, developing work activity concomitant with the study was associated with shorter sleep duration ( $p=0.003$; OR: 1,454; 95\% Cl: 1,135-1,862). The other components of PSQI did not present statistically significant differences with the exercise or not of work.

In the univariate analysis, it was found that, among students who did not work, poor sleep quality was associated with dissatisfaction with health $(p=0.014)$, dissatisfaction with studies $(p=0.045)$ and interference of study demand on life $(p=0.034)$. Few leisure opportunities $(p=0.049)$, dissatisfaction with health $(p<0.001)$, poor perception of quality of life $(p=0.003)$, difficulty reconciling personal life and studies $(p=0.001)$, interference of study demand about life $(p=0.002)$, anxiety due to academic activities $(p=0.004)$ and thinking about dropping out of the course $(p=0.002)$ were associated with poor sleep quality among students who performed work activity.

In Table 3, there are multiple models with factors associated with poor sleep quality.

Among students who did not perform work, satisfaction with health significantly reduced the chances of poor sleep quality. For students who reconciled studies and work, satisfaction with health was also a protective factor; however, the difficulty of reconciling personal and academic life and indicating anxiety due to school activities increased the chances of poor sleep quality.

\section{DISCUSSION}

Numerically, young women predominated, corroborating studies found in the literature, with a slight difference between the age thresholds presented ${ }^{(16-19)}$. Proportionally, men over the age of 30 years, with children and who lived with their families were those who reconciled the work day with study. In this sense, it is important to indicate the return to school for better relocation in the labor market, due to family obligations, improve monthly income and seek a work identity ${ }^{(20-21)}$.

Research indicated that the double work-study day, especially when work is performed at night, led to difficulty sleeping during the day, compromising health and social relationships, affecting academic life, because the permanence in studies depends on the organization of working life ${ }^{(22)}$.

The students surveyed who performed work activity reported few leisure opportunities. It is noteworthy that the low time reserved for leisure can directly influence students' quality of life, causing them to neglect self-care, overload the emotional and reflect on the low learning income ${ }^{(23)}$.

Poor sleep quality was a percentage higher in students who worked than those who did not work and the worse perception of sleep latency occurred among students who did not work, while developing work activity concomitant with the study was associated with shorter sleep duration. The shorter sleep duration in students who worked can be explained by academic demand, which requires the fulfillment of internships at other times and the performance of activities related to the study, such as research and alike. Students who work and study need a daily planning to take advantage of available time, making their choice to have a constant and adequate period of sleep is not their priority, but rather the execution of student activities ${ }^{(13,24)}$.

For students who did not work, sleep latency may be increased due to the time used for reading or spent with some electronic device ${ }^{(25)}$. Literature indicated that complaints of sleep and tiredness, reduced sleep duration, increased demand for responsibilities and shorter time to perform course activities provided poor sleep quality ${ }^{(26)}$.

It was also identified that, among students who worked or not, poor sleep quality was associated with dissatisfaction with health. Research indicated that students at different times of their graduation were satisfied with their health ${ }^{(27-29)}$. Dissatisfaction with health is shown by negative feelings related to the physical, psychological and social domains of students, directly interfering in their response to what they consider as quality of life ${ }^{(26)}$.

Research showed that the positive perception of health was directly linked to quality of life, as both function as a factor of protection and coping in daily activities and in the development of more actions in the health promotion of students ${ }^{(7)}$.

The results also show that the difficulty of reconciling personal life and studies was associated with poor sleep quality among students who worked. In this sense, it is a fact that studying and working concomitantly can generate negative feelings, poor mood, anxiety and despair, leading academics to the feeling of helplessness and willingness to give up the course ${ }^{(30)}$.

Another study showed a relationship between the difficulty in the academic and personal trajectory of working students, such as late entry into teaching, financial difficulties and reconciling study and work and unsatisfactory academic performance ${ }^{(20)}$. It is inferred that working and studying at the same time causes overload to individuals, which can culminate in physical and mental health problems.

Students often make the choice for private educational institutions, because they offer the largest number of vacancies and courses 
part-time, allowing the continuity of work. It should be noted that other difficulties, such as time dedicated to study and the interference of time to work, lead to delays and committed lunch hours, since there is a need to reconcile the two with their personal, family and social needs, reducing the time to sleep and its restorative function ${ }^{(20)}$.

In an investigation developed with undergraduate nursing students from a public university, it was revealed that students with employment had worse sleep quality, regardless of weekly workload $^{(31)}$. The extensive load of daily activities and the reduced rest time per night affect comprehension and learning, besides causing the unwillingness to learn the contents taught in the classroom, generating anxiety and thought of dropping out of the course, also influenced by personal and financial issues ${ }^{(32)}$.

The results showed that, among working students, anxiety due to school activities increased the chances of poor sleep quality. Among the potential stressors for students, there is too much academic responsibilities, the high amount of curricular activities and workload, the need to complement extra-class studies, the reconciliation between academic requirements and family and social life, concerns with assessments and learning and conflicting relationships with parents, teachers and classmates ${ }^{(33)}$.

Research on sleep quality indicated that the majority of nursing students surveyed had poor sleep quality, especially among those who studied and worked, was significantly higher ${ }^{(22)}$. Although the present study did not show significant differences, these data are similar to those obtained; however, they cannot be trivialized, since sleep alterations have been associated with increased morbidity and mortality in people. This result may have occurred due to the need and what represents the study for these students: the efforts undertaken to overcome the difficulties, i.e., the individual capacity that people have to modify and decrease adversities in the face of negative factors ${ }^{(34)}$.

It is worth emphasizing that the difficulties in reconciling academic life with work culminate in the impairment of quality of life in general, because there is deprivation of leisure due to lack of time and a daily life not favorable to the desired, becoming a challenge and leaving them vulnerable to illness due to the double or triple works. Thus, students look for ways to improve their quality of life and the academic training process ${ }^{(20)}$.

\section{Study limitations}

One of the limits concerns the epidemiological design of a cross-sectional study, which makes it impossible to assess the temporal sequence and does not make it possible to assess the cause and effect. Furthermore, it was limited to having been performed only in four vocational nursing courses in a city in the countryside of Paraná, which makes it difficult to generalize the results, but may be the incentive to conduct other nationwide research. Furthermore, it is worth indicating incipience of research with the analyzed population, which may have been an obstacle to the construction of more information about vocational nursing courses, since data discussion occurred with investigations of students from other levels of training.

\section{Contributions to nursing}

The study brings significant knowledge to the context of students of professional nursing courses through the study of the phenomenon of poor sleep quality and the exercise of work activity and, thus, can serve as subsidies for actions to be planned and implemented among managers and students to reduce this problem. Furthermore, knowledge advances, because a population that needs to be the focus of other studies is investigated, since there are few investigations with students of vocational nursing courses. Thus, it is suggested to conduct intervention studies focused on time management and health promotion.

Thus, it is believed that the managers of training courses should be attentive to this problem and seek strategies to minimize them, taking a teaching and learning process that takes into account students as holistic human beings.

\section{CONCLUSIONS}

Working and studying interfered in students' sleep quality. Sleep latency was lower in students without employment, while shorter sleep duration was evidenced in working students. Satisfaction with health reduced the chances of poor sleep quality, regardless of whether or not they exercised work. Furthermore, the difficulty of reconciling personal and academic life and indicating anxiety due to school activities increased the possibilities of poor sleep quality among students who study and work concomitantly. Thus, the hypothesis of this study was rejected, because students who work did not have significantly higher chances of poor sleep quality compared to those who did not. However, it should be noted that sleep duration, a component of sleep quality, was lower among working students.

\section{REFERENCES}

1. Jagannath A, Taylor L, Wakaf Z, Vasudevan SR, Foster RG. The genetics of circadian rhythms, sleep and health. Hum Mol Genet. 2017;26(R2):R128-R138. https://doi.org/10.1093/hmg/ddx240

2. Watson NF, Badr MS, Belenky G, Bliwise DL, Buxton OM, Buysse D, et al. Recommended amount of sleep for a healthy adult: a joint consensus statement of the American Academy of Sleep Medicine and Sleep Research Society. J Clin Sleep Med. 2015;11(6):591-2. https:// doi.org/10.5664/jcsm.4758

3. Ferreria SC, Jesus TB, Santos AS. Sleep quality and cardiovascular risk factors in nursing students. Rev Eletr Gestão Saúde. 2015; 6(1):390-04. https://doi.org/10.5205/1981-8963-v12i10a237489p2573-2582-2018

4. Grandner MA. Sleep and obesity risk in adults: possible mechanisms; contextual factors; and implications for research, intervention, and policy. Sleep Health. 2017;3(5):393-400. https://doi.org/10.1016/j.sleh.2017.07.014 
5. Rhéaume A, Mullen J. The impact of long work hours and shift work on cognitive errors in nurses. J Nurs Manag. 2018;26(1):26-32. https:// doi.org/10.1111/jonm.12513

6. Nascimento ACM, Oliveira ER, Santos LS, Pena LSO. Sleep standard and student performance: a systematic review. Rev Edapeci. 2018;18(3):93-104. https://doi.org/10.29276/redapeci.2018.18.39998.93-104

7. Galván-Molina JF, Jiménez-Capdeville ME, Hernández-Mata JM, Arellano-Cano JR. Psychopathology screening in medical school students. Gac Med Mex [Internet]. 2017[cited 2020 Dec 10];153(1):75-87. Available from: https://pubmed.ncbi.nlm.nih.gov/28128809/

8. Wang Y, Xiao H, Zhang X, Wang L. The role of active coping in the relationship between learning burnout and sleep quality among college students in china. Front Psychol. 2020;11:647. https://doi.org/10.3389/fpsyg.2020.00647

9. Leyva-Vela B, Llorente-Cantarero FJ, Henarejos-Alarcón S, Martínez-Rodríguez A. Psychosocial and physiological risks of shift work in nurses: a cross-sectional study. Cent Eur J Public Health. 2018;26(3):183-9. https://doi.org/10.21101/cejph.a4817

10. Maier SRO, Mattos M. The work and study in the university context: an approach to working students. Saúde (Santa Maria). 2016;42(1):17985. https://doi.org/10.5902/2236583420477

11. Santos TCMM, Martino MMF, Sonati JG, Faria AL, Nascimento EFA. Sleep quality and chronotype of nursing students. Acta Paul Enferm. 2016;29(6):658-63. https://doi.org/10.1590/1982-0194201600092

12. Rabei S, Mourad G, Hamed AED. Work stress and sleep disturbances among internship nursing students. Middle East Curr Psychiatry. 2020;27(24). https://doi.org/10.1186/s43045-020-00032-1

13. Silva KKM, Martino MMF, Bezerra CMB, Souza ÂM, Silva DM, Nunes JT. Stress and quality of sleep in undergraduate nursing students. Rev Bras Enferm. 2020;73(Suppl-1):e20180227. https://doi.org/10.1590/0034-7167-2018-0227

14. Hosmer DWH, Lemeshow S, Sturdivant RX. Applied Logistic Regression. 3a edition. New York: Wiley; 2013.

15. Bertolazi AN, Fagondes SC, Hoff LS, Dartora EG, Miozzo ICS, Barba MEF, et al. Validation of the Brazilian Portuguese version of the Pittsburgh Sleep Quality Index. Sleep Medicine. 2011;12(1):70-5. https://doi.org/10.1590/S1806-37132009000900009

16. Cachoeira DVAC, Santos SCC, Menegant APS, Negreiros NF, Cardoso L, Preto VA. Relation of sociodemographic profile with the risk of illness by mental disorders common among students of the nursing course. Rev Enferm UFPE. 2016;10(12):4501-8. https://doi.org/10.5205/ reuol.9978-88449-6-ED1012201610

17. Chaves CM, Nelas PA, Cruz CM, Coutinho E, Amaral O. Socio-demographic and academic profile of nursing students and subject well-being. Int J Develop Educ Psychol. 2016;2(1):123-32. https://doi.org/10.17060/ijodaep.2016.n1.v2.224

18. Bublitz S, Guido LA, Kirchhof RS, Neves ET, Lopes LFD. Sociodemographic and academic profile of nursing students from four brazilian institutions. Rev Gaúcha Enferm. 2015;36(1):77-83. https://doi.org/10.1590/1983-1447.2015.01.48836

19. Paranhos WY, Chaves AAB, Frias MAE, Leite MMJ. Performance analysis of nursing students in teaching by skills and for understanding. Rev Esc Enferm USP. 2015;49(spe2):115-21. https://doi.org/10.1590/s0080-623420150000800016

20. Prebill GM, Corrêa AK. The nursing student - worker: a bibliographical study. Cienc Cuid Saude. 2018;17(4):42042. https://doi.org/10.4025/ cienccuidsaude.v17i4.42042

21. Silva M, Chaves C, Duarte J, Amaral O, Ferreira M. Sleep quality determinants among nursing students. Procedia Soc Behav Sci. 2016;217(5):999-1007. https://doi.org/10.1016/j.sbspro.2016.02.090

22. Santos TCMM, Martino MMF, Sonati JG, Faria AL, Nascimento EFA. Sleep quality and chronotype of nursing students. Acta Paul Enferm. 2016;29(6):658-63. https://doi.org/10.1590/1982-0194201600092

23. Bernardino AO, Coriolano-Marinus MWL, Santos AHS, Linhares FMP, Cavalcanti AMTS, Lima LS. Motivation of nursing students and their influence in the teaching-learning process. Texto Contexto Enferm. 2018;27(1):e1900016. https://doi. org/10.1590/0104-070720180001900016

24. Castilho CP, Limas LMD, Monteiro ML, Silva PHMN, Bueno H, Fari TA. Sleep deprivation in medical students in service at the basic health units and its consequences. Rev Med. 2015;94:113-9. https://doi.org/10.11606/issn.1679-9836.v94i2p113-119

25. Carone CMM, Silva BP, Rodrigues LT, Tavares OS, Carpena MX, Santos IS. Factors associated with sleep disorders in university students. Cad Saúde Pública. 2020;36(3):e00074919. https://doi.org/10.1590/0102-311x00074919

26. Obrecht A, Collaço I, Valderramas S, Miranda K, Vargas E, Szkudlarek A. Analysis of sleep quality in undergraduate students of different shift. Rev Neurociências. 2015;23(2):205-10. https://doi.org/10.4181/rnc.2015.23.02.998.6p

27. Moura IH, Nobre RS, Cortez RMA, Campelo V, Macêdo SF, Silva ARV. Quality of life of undergraduate nursing students. Rev Gaúcha Enferm. 2016;37(2):e55291. https://doi.org/10.1590/1983-1447.2016.02.55291

28. Barbosa T, Zica M, Quaresma F, Sonati J, Batello G, Maciel E. Percepção de estresse e qualidade de vida dos acadêmicos de enfermagem no Brasil. Rev UILPS. 2016;4(2):94-102. https://doi.org/10.25746/ruiips.v4.i2.9922

29. Carleto CT, Cornélio MPM, Nardelli GG, Haas VJ, Pedrosa LAK. Saúde e qualidade de vida de universitários da área da saúde. REFACS. 2019;7:53-63. https://doi.org/10.18554/refacs.v7i1.2966

30. Moritz AR, Pereira EM, Borba KP, Clapis MJ, Gevert VG, Mantovani MF. Quality of life of undergraduate nursing students at a Brazilian public university. Invest Educ Enferm. 2016;34(3):564-72. https://doi.org/10.17533/udea.iee.v34n3a16 
31. Lopes HS, Meier DAP, Rodrigues R. Sleep quality among nursing students and associated factors. Semina Cienc Biol Saude. 2018;39(2):12936. https://doi.org/10.5433/1679-0367.2018v39n2p129

32. Barros MJ, Borsari CMG, Fernandes AO, Silva A, Filoni E. Evaluation of quality of life in college students of the health area. Rev Bras Educ Saúde. 2017;7(1):16-22. https://doi.org/10.18378/rebes.v7i1.4235

33. Benavente SBT, Silva RM, Higashi AB, Guido LA, Costa ALS. Influence of stress factors and socio-demographic characteristics on the sleep quality of nursing students. Rev Esc Enferm USP. 2014. https://doi.org/10.1590/s0080-623420140000300018

34. Souza MR, Caldas TCG, Antoni C. Illness factors of students in health area: a systematic review. Psicol Saúde Debate. 2017;3(1):99-126. https://doi.org/10.22289/2446-922X.V3N1A8 